ISSN: 2224-0616

Int. J. Agril. Res. Innov. \& Tech. 3 (2): 59-65, December, 2013 Available online at http:// www.ijarit.webs.com

\title{
FEASIBILITY STUDY OF CASSAVA MEAL IN BROILER DIETS BY PARTIAL REPLACING ENERGY SOURCE (CORN) IN REGARD TO GROSS RESPONSE AND CARCASS TRAITS
}

\author{
M.A. Hossain 1* J.R. Amin² and M.E. Hossain ${ }^{3}$
}

Received 27 September 2013, Revised 20 December 2013, Accepted 25 December 2013, Published online 31 December 2013

\begin{abstract}
Day-old unsexed broiler chicks (Cobb 500) were used to investigate the growth responses and meat yield traits by nourishing them under four dietary treatment group in inclusion of cassava meal with partial substitution of valuable energy source (maize or corn). A total of 260 birds were assigned randomly into four dietary treatments $\left[\mathrm{T}_{1}(0 \%) ; \mathrm{T}_{2}(10 \%) ; \mathrm{T}_{3}(20 \%)\right.$, and $\mathrm{T}_{4}(30 \%)$; ; each replicated 5 times, 13 birds/replicate in a completely randomized design. Birds were reared with ad libitum feeding, similar housing, and environmental management condition from d1-35 days. Growth responses of broilers in terms of feed intake, body weight, feed conversion ratio (FCR), livability and meat yield traits were assessed in this study. Except for first week, the feed intake of birds on cassava treated diets up to 21 and 35 days was significantly ( $<<0.001$ ) higher than the non-cassava or control diet $\left(T_{1}\right)$. Feed intake of broilers on cassava treated diet $\left(T_{4}\right)$ had the highest $(2795.8 \mathrm{~g} / \mathrm{b})$ while the birds of control $\left(T_{1}\right)$ diet group consumed the lowest feed $(2771.9 \mathrm{~g} / \mathrm{b})$ at 35 day. Live weight decreased $(p<0.001)$ with the inclusion of cassava meal diets up to 21 day only; and live weights up to 7 and 35 days were identical between treatment. FCR up to 21 day was improved $(\mathrm{p}<0.001)$ on control diet $\left(\mathrm{T}_{1}\right)$ and deteriorated on cassava treated diets. FCR values up to 7 and 35 days were unaffected by all the treatment groups. Neither the livability nor the meat yield traits (thigh, breast, drumstick, shank, neck, giblet, wing and dressing yield) of broiler chickens was influenced by the dietary treatments regardless of feeding broiler chickens with cassava or non-cassava diets in this study. It may be deduced based on the present findings that, cassava tuber meal might be a potential ingredient to replace the costly maize up to $300 \mathrm{~g} \mathrm{~kg}^{-1}$ without affecting growth performance of the broiler chickens.
\end{abstract}

Keywords: Cassava Tuber Meal, Performance, Meat Yield Characteristics

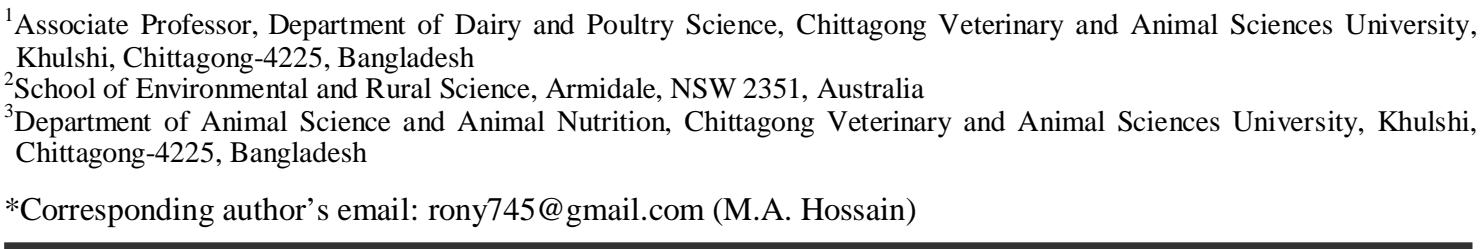

\section{Introduction}

In poultry production, feed costs are the principal cost encompassing more than $70 \%$ (McNab, 1999), of which dietary energy sources occupy the greatest portion (70 -75\% of the diets) (Van der Klis et al., 2010). Birds have a normal tendency to eat feeds mainly to gratify their energy requirements and once this is satisfied, they won't show any trend to consume any more feeds, even if the requirements of other nutrients like protein, vitamins or minerals have not been met (Singh and Panda, 1992). For this reason, the energy ingredients of the diets play a pivotal role in diet formulation for poultry. Most of the energy ingredients come from plant sources in the form of starch from cereal grains. Corn/maize and wheat are the main cereal grains that are used predominantly as energy sources for manufacturing poultry diet. These cereal grains provide the energy component which accounts for
60 to $70 \%$ of the nutrient requirement for the poultry.

However, the considerable increase in the cost of poultry diets round the world has been driven a force to search for cheaper sources of dietary energy to be used to partially substitute the cereal grains traditionally used in broiler diets (Stevenson and Jackson, 1983). Cassava tuber meal might be as an alternative energy source to replace the costly cereal grains (corn/wheat), and to minimize the feed cost for poultry production. Its use in animal feeds not new, and its cultivation in the tropical countries are predominant. Africa alone is produced around $50 \%$ cassava of the world. Besides this, Nigeria, Brazil and Thailand are the most important cassava producing countries, with Thailand being the world's leading cassava exporter (Garcia and Dale, 1999). 
Under tropical conditions cassava (Manihot esculenta), a tuber, is the most productive crop in terms of stability of production and high energy yield per unit of land area (Oke, 1978; Okezie et al., 1982; Ravindran and Blair, 1991). Cassava root meal is mainly a source of energy, with a high starch content (about $60-70 \%$ ), and the yield may be counted less than 12.5 tonnes acre-1. However, the level of protein is very low, being approximately $2.5 \%$ of dry matter (Garcia and Dale, 1999).

The preconditions of profitable poultry business depend on the availability of quality feed ingredients at reasonable price. As major energy components (50-70\%), maize and wheat are being used traditionally in poultry and other mono-gastric animal's diet formulations for long since (PAN, 1995). Apart from this, these ingredients (corn/wheat) are also being used to meet the ever increasing food demand of human beings. Owing to this food-feed competition between animals and human beings, the cost of cereal grains is going up day by day. High feed cost hardly permits remunerative and profitable poultry farming. Therefore, the use of cereal products as livestock feed is being increasingly unjustified in terms of economic stand point. Besides, the low production and high demand of cereal grains for both men and animals have been creating constant force to explore other potential energy sources (Raihan et al., 2008). Therefore, there is a need to explore cheaper energy sources, to replace expensive cereals for livestock production, and to ease the food-feed competition in the future.

However, using inexpensive, unconventional feeds, locally available ingredients in poultry diets by replacing the costly grains, can become an effective way to minimize the feed cost and maximize the profitability of broiler chickens suggested by the Nutritionists (Hossain et al., 1989). For this reason, in the past few decades, many efforts have been made to replace cereals with other carbohydrate sources, for example, sorghum, lentils, or cassava tuber meal (Garcia and Dale, 1999), Leucaena root meal (Bhatnagar et al., 1996) in poultry feed. Cassava (M. esculenta) can be given more emphasis for using in poultry diets amongst others, because of its better yield, and rich in starch (60 to 70\%) content. Furthermore, cassava is an important food crops grown in the tropical areas (Hahn, 1989; Phillips et al., 2004) like Africa, where it provides a significant amount of energy for 500 million people (Mroso, 2003). If we can process properly the anti-nutritive factor ( $\mathrm{HCN})$ found in cassava meal can be minimized to non-toxic level (Padmaja, 1995). With the light of above advantages, the study was undertaken to investigate the growth responses and meat yield characteristics of broiler chickens fed diets incorporating with cassava tuber meal by partial replacement with corn.

\section{Materials and Methods}

\section{Animal husbandry and bird management}

A total of 260 day-old (Cobb 500) unsexed commercial broiler chicks were used to conduct this experiment. The chicks were divided randomly into 4 dietary treatment groups $\left[\mathrm{T}_{1}, \mathrm{~T}_{2}\right.$, $\mathrm{T}_{3}$ and $\mathrm{T}_{4}$ ]; each treatment replicated 5 times, 13 birds per replicate in a completely randomized design. The birds were reared under floor-pen system in a wire-netted house from d1 to 35 days. A total of 20 wire-netted pens of equal size $(140 \times$ $90 \mathrm{~cm}$ ) were set up in a shed type house to accommodate the birds. Each pen was designed for 13 birds, and was equipped with a feeder and a drinker to supply diets and water ad libitum for the birds throughout the trial period. Rice husk litter materials to a depth of $2.5 \mathrm{~cm}$ were spread over the floor of each pen to maintain comfortable environment.

The birds were brooded at $33 \circ \mathrm{C}$ for the first two days, and then the temperature was reduced gradually to $24^{\circ} \mathrm{C}$ at 19 days of age, and maintained at this level to the end of the trial. Continuous lighting (23 hours light and 1 hour darkness) including the natural light and electrical bulb was provided the birds throughout the trial period. All the birds received the necessary vaccines against Newcastle disease, Infectious bursal diseases and Infectious Bronchitis disease and some medication for disease protection and immunity.

\section{Dietary treatment \\ Processing cassava tuber}

Collected cassava tubers were cleaned by removing dust, sand or any other foreign materials attached with these ingredients, then they were sliced, chopped, crushed and dried in the sunlight for 3 days. After drying tubers, meal was prepared by grinding sun-dried cassava tuber slices in a Mortar and Pestle. After that, these ground cassava meal (CM) was used in formulating diets at various dietary levels of 0 , 100,200 , and $300 \mathrm{~g} \mathrm{~kg}^{-1} \mathrm{CM}$ by replacing maize (shown below in Tables 1 and 2).

\section{Formulation of diets}

Four experimental diets, identified as $T_{1}, T_{2}, T_{3}$ and $\mathrm{T}_{4}$ were formulated with maize, cassava meal, and vegetable oil as main energy sources, along with soybean meal and fishmeal as protein ingredients (Tables 1 and 2). Except for diet $\mathrm{T}_{1}$, cassava meal was included at the rate of $10 \%$, $20 \%$ and $30 \%$ in $\mathrm{T}_{2}, \mathrm{~T}_{3}$ and $\mathrm{T}_{4}$ diets, respectively, by replacing the corn. All the diets were prepared to meet or exceed NRC (1994) recommendations, and supplied the birds in mash form in both starter and finisher period. All diets were isocaloric and iso-nitrogenous and supplemented with exogenous microbial enzymes (Avizyme 0.5g and Phyzyme $0.1 \mathrm{~g} \mathrm{~kg}^{-1}$ of each diet, Danisco Animal Nutrition, UK). Starter diets were fed the birds for the first three weeks, and finisher diets were used for rest of the trial period ( 22 to $35 \mathrm{~d}$ ). 
Table 1. Starter broiler diets

\begin{tabular}{lcccc}
\hline Ingredients (\%) & \multicolumn{4}{c}{ Diets } \\
\cline { 2 - 5 } & $\mathrm{T}_{1}$ & $\mathrm{~T}_{2}$ & $\mathrm{~T}_{3}$ & $\mathrm{~T}_{4}$ \\
\hline Corn & 60.00 & 54.00 & 48.00 & 42.00 \\
Cassava meal & 0.00 & 6.00 & 12.00 & 18.00 \\
Soybean meal & 22.80 & 23.00 & 24.00 & 24.20 \\
Fishmeal & 8.30 & 8.60 & 8.60 & 9.00 \\
Limestone & 3.00 & 3.00 & 3.00 & 2.40 \\
Dicalcium phosphate & 4.50 & 4.10 & 3.10 & 3.10 \\
DL-methionine & 0.21 & 0.21 & 0.21 & 0.21 \\
L-Lysine & 0.19 & 0.19 & 0.19 & 0.19 \\
Table salt(NaCl) & 0.50 & 0.50 & 0.50 & 0.50 \\
1Vit- min-premix & 0.25 & 0.25 & 0.25 & 0.25 \\
Choline Chloride & 0.06 & 0.06 & 0.06 & 0.06 \\
Avizyme 1502 & 0.05 & 0.05 & 0.05 & 0.05 \\
PhyzymeXP & 0.01 & 0.01 & 0.01 & 0.01 \\
\hline Nutrient content & & & 12.70 & 12.70 \\
\hline ME (M)/kg) & 12.70 & 12.80 & 21.00 & 21.00 \\
CP (\%) & 21.00 & 2.00 & 2.60 & 2.70 \\
CF (\%) & 3.40 & 2.10 & 2.03 & 2.00 \\
EE (\%) & 1.70 & 2.00 & 1.80 & 1.64 \\
Ca (\%) & 2.00 & 0.91 & 0.73 & 0.73 \\
Av.P(\%) & 0.98 & 0.24 & 0.23 \\
Na (\%) & 0.24 & 0.34 & 0.34 & 0.33 \\
Cl (\%) & 0.35 & 1.30 & 1.32 & 1.31 \\
Lysine(\%) & 1.31 & 1.30 & 1.30 & 1.29 \\
Arginine(\%) & 1.29 & 0.57 & 0.56 & 0.55 \\
Methionine(\%) & 0.58 & & & \\
\hline
\end{tabular}

1Provided per kg of diet (mg): vitamin A (as all-trans retinol), $3.6 \mathrm{mg}$; cholecalciferol, $0.09 \mathrm{mg}$; vitamin E (as d- $\alpha$ tocopherol ), $44.7 \mathrm{mg}$; vitamin $\mathrm{K}_{3}, 2 \mathrm{mg}$; thiamine, $2 \mathrm{mg}$; riboflavin, $6 \mathrm{mg}$; pyridoxine hydrochloride, $5 \mathrm{mg}$; vitamin $\mathrm{B}_{12}$, $0.2 \mathrm{mg}$; biotin, $0.1 \mathrm{mg}$; niacin, $50 \mathrm{mg}$; D- calcium pantothenate, $12 \mathrm{mg}$; folic acid, $2 \mathrm{mg} ; \mathrm{Mn}, 80 \mathrm{mg}$; Fe, 60 mg; Cu, 8 mg; I, 1mg; Co, 0.3 mg and Mo, 1mg.

Table 2. Finisher broiler diets

\begin{tabular}{|c|c|c|c|c|}
\hline \multirow{2}{*}{ Ingredients (\%) } & \multicolumn{4}{|c|}{ Diets } \\
\hline & $\mathrm{T}_{1}$ & $\mathrm{~T}_{2}$ & $\mathrm{~T}_{3}$ & $\mathrm{~T}_{4}$ \\
\hline Corn & 59.00 & 53.10 & 47.20 & 41.30 \\
\hline Cassava meal & 0.00 & 5.90 & 11.80 & 17.70 \\
\hline Vegetable oil & 0.70 & 0.70 & 1.70 & 2.10 \\
\hline Soybean meal & 21.10 & 22.00 & 23.00 & 24.00 \\
\hline Fishmeal & 8.20 & 8.20 & 8.20 & 8.20 \\
\hline Limestone & 4.00 & 3.32 & 2.67 & 2.27 \\
\hline Dicalcium phosphate & 5.60 & 5.50 & 4.10 & 3.10 \\
\hline DL-methionine & 0.21 & 0.21 & 0.21 & 0.21 \\
\hline L-Lysine & 0.19 & 0.19 & 0.19 & 0.19 \\
\hline Table salt (NaCl) & 0.50 & 0.50 & 0.50 & 0.50 \\
\hline 1Vit- min-premix & 0.25 & 0.25 & 0.25 & 0.25 \\
\hline Choline Chloride & 0.06 & 0.06 & 0.06 & 0.06 \\
\hline Avizyme 1502 & 0.05 & 0.05 & 0.05 & 0.05 \\
\hline PhyzymeXP & 0.01 & 0.01 & 0.01 & 0.01 \\
\hline \multicolumn{5}{|l|}{ Nutrients content } \\
\hline $\mathrm{ME}(\mathrm{MJ} / \mathrm{kg})$ & 12.90 & 12.90 & 12.90 & 12.90 \\
\hline $\mathrm{CP}(\%)$ & 20.00 & 20.00 & 20.00 & 20.00 \\
\hline CF (\%) & 3.30 & 3.40 & 3.40 & 3.50 \\
\hline EE (\%) & 1.60 & 1.60 & 1.50 & 1.40 \\
\hline $\mathrm{Ca}(\%)$ & 2.40 & 2.30 & 2.00 & 2.00 \\
\hline Av.P (\%) & 1.30 & 1.20 & 1.00 & 1.00 \\
\hline $\mathrm{Na}(\%)$ & 0.25 & 0.23 & 0.24 & 0.23 \\
\hline $\mathrm{Cl}(\%)$ & 0.35 & 0.34 & 0.34 & 0.33 \\
\hline Lysine (\%) & 1.25 & 1.26 & 1.27 & 1.28 \\
\hline Arginine (\%) & 1.29 & 1.30 & 1.30 & 1.29 \\
\hline Methinine (\%) & 0.56 & 0.55 & 0.55 & 0.54 \\
\hline
\end{tabular}

1Provided per kg of diet (mg): vitamin A (as all-trans retinol), $3.6 \mathrm{mg}$; cholecalciferol, $0.09 \mathrm{mg}$; vitamin E (as d- $\alpha$ tocopherol ), $44.7 \mathrm{mg}$; vitamin $\mathrm{K}_{3}, 2 \mathrm{mg}$; thiamine, $2 \mathrm{mg}$; riboflavin, $6 \mathrm{mg}$; pyridoxine hydrochloride, $5 \mathrm{mg}$; vitamin $\mathrm{B}_{12}$, $0.2 \mathrm{mg}$; biotin, $0.1 \mathrm{mg}$; niacin, $50 \mathrm{mg}$; D- calcium pantothenate, $12 \mathrm{mg}$; folic acid, $2 \mathrm{mg}$; $\mathrm{Mn}, 80 \mathrm{mg}$; $\mathrm{Fe}, 60 \mathrm{mg} ; \mathrm{Cu}, 8 \mathrm{mg}$; I, 1mg; Co, $0.3 \mathrm{mg}$ and Mo, 1mg. 


\section{Data collection}

Body weight and feed intake data of the birds were recorded weekly. Mortality was recorded as it occurred. Feed conversion ratio was calculated weekly, and corrected for mortality. At the end of the trial period (35d), two birds from each pen were randomly selected, weighed and killed humanely to measure different body parts (thigh, shank, breast, giblet, neck, wing, drumstick and dressed yield) of the birds. These were described below.

Performance indices: Data were collected weekly on the parameters listed below:

Feed intake: Feed intakes of broiler chickens were assessed weekly basis. The amount of feeds served the birds and what were left unconsumed (collected daily) were weighed weekly. Then weekly feed intake was obtained from the difference of the amount of feed consumed by the birds and the left-over found in each replicate cage. To obtain the consumption per day, weekly feed intake was divided by 7 and the value further divided by the number of birds in each replicate to get consumption per day per bird.

Body weight and weight gain: Body weights of broiler chickens were also assessed weekly. Chicks were weighed initially in group (each replicate cage) before distributing them into each replicate cage. Weights of the birds in different replicates were taken weekly, and weights gained for the week were obtained by deducting the weekly average weight of each bird from the initial weight of the birds. The values were divided by the number of chicks to get gain per chick per week and from this gain per day was calculated as below:

Body weight gain = Weekly acquired body weight (g) - Initial body weight (g)

Feed/gain ratio or feed conversion ratio (FCR): The unit of feed needed per unit of production is called feed conversion ratio. This was calculated as the ratio of the feed consumed to the weight gained as follows:

$$
\mathrm{FCR}=\frac{\text { Amount of feed consumed }}{\text { Fudy weight guin }}
$$

Livability (\%): The percentage of livability was calculated by deducting mortality from hundred each replicate wise.

Organs and carcass yields studies: On the last day of the trial period (35d), two birds from each replicate cage $(2 \times 5 \times 4=40$ birds) representing the average body weight were randomly selected, weighed and slaughtered humanely. After slaughtering and bleeding, the birds were scalded and feathers were plucked. Carcasses were eviscerated, heads and shanks were separated, then the carcasses were chilled in a tap water for about 5 to 10 minutes. Eviscerated carcasses were individually weighted and dressing percentage was calculated (weight of carcass + giblet + abdominal fat/pre-slaughter weight $\times 100$ ). The relative weights of other organs of carcass, for example, shank, neck, giblet (liver + heart + gizzard), thigh, drumstick, breast and wing weights were measured each replicate wise.

\section{Statistical analysis}

Statistical analyses were performed using Minitab software (Minitab version 15, 2000). The data were analyzed using one-way ANOVA with diet as factor. The significance of difference between means was determined by Fisher's least significant difference at $\mathrm{p} \leq 0.05$.

\section{Results}

\section{Gross responses}

The results of gross responses of broilers in terms of feed intake, live weight and feed conversion ratio are shown in Table 3; and livability of birds is presented graphically below (Fig. 1).

\section{Feed intake}

The results of feed intake of broilers up to 7 day were identical between dietary treatment groups (Table 3). Except for first week, the feed intake up to 21 and 35 days differed significantly $(\mathrm{p}<0.001)$ between treatment. Birds on $\mathrm{T}_{4}$ diet group had the highest feed intake while the birds on $\mathrm{T}_{1}$ dietary group consumed the lowest feed during 21 and 35 days, respectively. The feed consumption of broilers on $\mathrm{T}_{1}$ diet group was similar to the birds on $\mathrm{T}_{2}$ diet group during 21 and 35 days, respectively.

Table 3. Feed intake (FI), live weight (LW), feed conversion ratio (FCR), of broiler chickens fed different diets from d1-35

\begin{tabular}{|c|c|c|c|c|c|c|}
\hline & Age (day) & \multicolumn{4}{|c|}{ Dietary Treatments } & \multirow{2}{*}{$\begin{array}{c}\text { Pooled } \\
\text { SEM }\end{array}$} \\
\hline & & $\mathrm{T}_{1}$ & $\mathrm{~T}_{2}$ & $\mathrm{~T}_{3}$ & $\mathrm{~T}_{4}$ & \\
\hline \multirow{4}{*}{$\mathrm{FI}(\mathrm{g} / \mathrm{b})$} & $1-7$ & 135.8 & 132.6 & 133.0 & 129.3 & 1.23 \\
\hline & $1-21$ & $974.3^{\mathrm{b}}$ & $983.7 \mathrm{~b}$ & $994.7 \mathrm{ab}$ & $1000.6^{\mathrm{a}}$ & 1.63 \\
\hline & $1-35$ & $2771.9^{c}$ & $2779.9^{c}$ & $2787.3^{\mathrm{b}}$ & $2795.8^{a}$ & 1.29 \\
\hline & $1-7$ & 134.1 & 132.3 & 131.0 & 128.1 & 0.73 \\
\hline \multirow[t]{3}{*}{ LW (g/b) } & $1-21$ & $641.4^{a}$ & $632.8^{\mathrm{b}}$ & $622.4^{c}$ & $614.9^{d}$ & 1.05 \\
\hline & $1-35$ & 1437.7 & 1424.8 & 1430.1 & 1415.7 & 9.08 \\
\hline & $1-7$ & 1.55 & 1.55 & 1.59 & 1.59 & 0.023 \\
\hline \multirow[t]{2}{*}{ FCR } & $1-21$ & $1.64 \mathrm{~d}$ & $1.68 \mathrm{c}$ & $1.73^{b}$ & $1.76^{a}$ & 0.004 \\
\hline & $1-35$ & 2.00 & 2.10 & 2.12 & 2.13 & 0.013 \\
\hline
\end{tabular}

Data represent means of five replicates consisting of 13 birds per replicate during d1-35 days; a,b,c,dMeans bearing uncommon superscript within a row are significantly different at $* * * \mathrm{p}<0.001$; $\mathrm{SEM}=\mathrm{Standard}$ error of mean. 


\section{Live weight}

Live weight was similar between the treatment during first and fifth weeks. Apart from this, live weight up to $21 \quad(\mathrm{p}<0.001)$ days differed significantly between the treatment. Bird on control $\left(\mathrm{T}_{1}\right)$ diet had the highest body weight while the birds on $\mathrm{T}_{4}$ diet being the least at 21day.

\section{Feed conversion ratio (FCR)}

FCR did not affect significantly ( $p>0.001)$ during first and fifth weeks only. After that, FCR up to 21 days significantly improved ( $\mathrm{p}<0.001)$ between the treatment. Birds on $\mathrm{T}_{1}$ diet group had the superior FCR while the birds on $\mathrm{T}_{4}$ diet group being the poorest during 21day.

\section{Livability (\%)}

The Livability of broilers of different dietary group was $96.9 \%, 95.4 \%, 95.4 \%$, and $96.9 \%$ in $\mathrm{T}_{1}$, $\mathrm{T}_{2}, \mathrm{~T}_{3}$ and $\mathrm{T}_{4}$ treatment groups, respectively, but did not differ significantly at 35 day (Fig. 1).

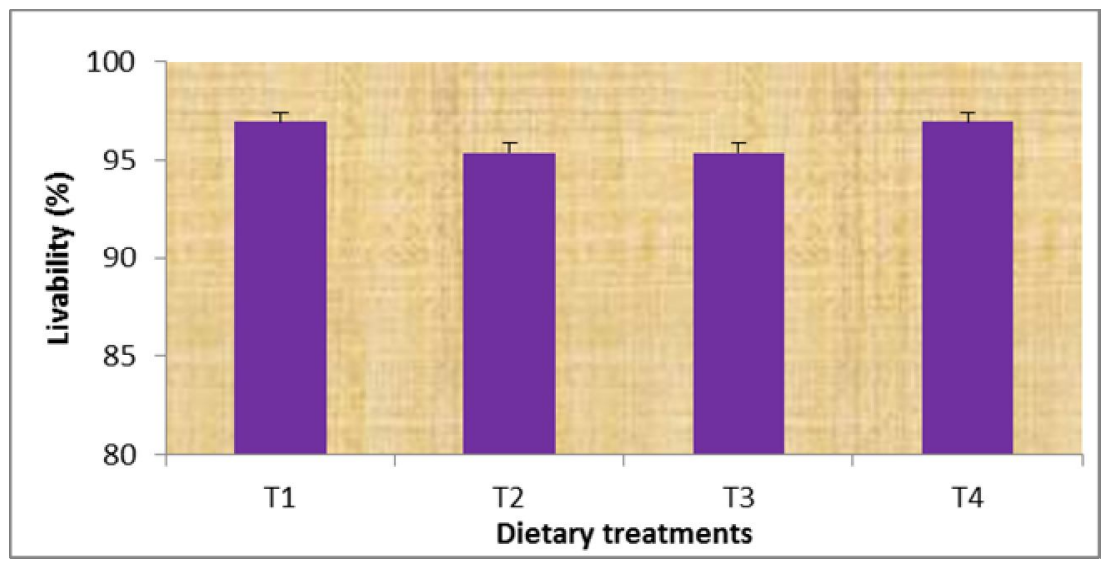

Fig. 1. Livability (\%) of broilers of different dietary groups at 35 day (values mean $\pm \mathrm{SE}$ )

\section{Meat yield characteristics}

The results of meat yield of different body parts (thigh, breast, drumstick, shank, neck, giblet, wing and dressing yield) of broilers fed different diets are shown in Table 4 . All the body parts measured in this study were found to be similar between the treatment without affecting significantly. Apart from this, thigh, breast, drumstick, neck and wing weights $(\mathrm{g} / \mathrm{b})$ of broilers of different dietary treatments are tended to be significant ( $\mathrm{p}=0.064$ to 0.099 ).

Table 4. Meat yield $(\mathrm{g} / \mathrm{b}$ ) of various body parts of broilers fed different diets at age of $35 \mathrm{~d}$

\begin{tabular}{lccccc}
\hline \multirow{2}{*}{ Parameters } & \multicolumn{4}{c}{ Dietary Treatments } & \multirow{2}{*}{ Pooled SEM } \\
\cline { 2 - 5 } Live weight $(\mathrm{g} / \mathrm{b})$ & $\mathrm{T}_{1}$ & $\mathrm{~T}_{2}$ & $\mathrm{~T}_{3}$ & $\mathrm{~T}_{4}$ & \multirow{2}{*}{} \\
\cline { 2 - 5 } Shank weight & 1437.7 & 1424.8 & 1430.1 & 1415.7 & 1.08 \\
Neck weight & 52.2 & 48.1 & 46.3 & 46.1 & 1.12 \\
Giblet weight & 50.7 & 46.7 & 48.6 & 42.2 & 1.36 \\
Thigh weight & 87.7 & 87.3 & 78.7 & 82.3 & 0.40 \\
Drumstick weight & 134.0 & 131.1 & 132.4 & 131.5 & 1.14 \\
Wing weight & 131.5 & 124.7 & 126.2 & 122.6 & 0.89 \\
Breast weight & 129.3 & 125.8 & 125.2 & 121.5 & 2.13 \\
Dressing(\%) & 237.1 & 227.4 & 222.5 & 223.0 & 0.35 \\
\hline
\end{tabular}

Data represent mean values of two chicken of five replicate groups at age of 35d; SEM-Standard error of mean

\section{Discussion}

\section{Feed intake}

Feed intake of broilers on cassava treated diets was significantly increased throughout the trial period with having no effect on first week only. It would appear from the feed consumption of broilers on cassava treated diets that, cassava meals does not affect palatability of the feeds. So the increased feed intake of broilers on cassava meal diets in this study might be resulted from the palatability of feeds and some other factors might stimulate birds to ingest higher feeds (Tewe, 1993; Maust et al., 2000; Onjoro et al., 2001; Onyimoyi and Ugwu, 2007). However, feed intake was improved by inclusion of cassava meal (CM). It implied that CM did not hamper the palatability of the formulated diets used in this 
study. On the other hand, the impaired feed intake of broilers offered on non-cassava meal diet may be possibly due to reduced palatability of the diets. Lower palatability of the diets might be another reason for reduced feed consumption by the broiler chickens (Mahmoudnia et al., 2011). Other deleterious substances which may be present in the diets are protease inhibitors, lectins, polyphenolic compounds, saponins, HCN, tannin and non-starch polysaccharides (Reed et al., 1982; Piva, 1987; Hughes and Choct, 1999 ), can also affect the feed consumption.

\section{Live weight}

Except for 21 day, the live weight of birds offered with cassava treated diets or non-cassava meal diet was found to be similar in this study. However, live weight of broiler was slightly decreased on cassava treated diets during mid growth point (21 day). This result was agreed with the Vogt (1966) who also found depressed performance of broilers by feeding cassava diets. Reduction of live weight may be due to the high level of fiber and poor protein contents in cassava meal diets which could reduce the digestibility of diets and subsequently affected the growth of broilers (Akintala et al., 2002) at this stage. Apart from this, live weight of broilers on either diet groups was unaffected during first week and 35 days, respectively. These results are agreed with the findings of Stevenson and Jackson (1983) who found similar results either treating cassava meal diets or non-cassava meal diets to the broiler chickens.

\section{Feed Conversion Ratio (FCR)}

FCR values were unaffected between the treatments up to 7 and 35 days except for 21 day. FCR values of broilers were impaired by feeding cassava treated diets during 21 day. This would imply that birds fed diets with cassava meals demonstrated poorer feed efficiency during this period than the birds on non-cassava diets. The reason may be explained that cassava treated diets might have lower digestibility and lower protein and amino acids which might influence the feed efficiency of the broiler chickens. Moreover, some deleterious factors (HCN, tannin) are found in cassava meal (Reed et al., 1982; Stevenson and J ackson, 1983; Ravindran et al.,1987; Garcia and Dale,1999), which might also affect the FCR of broiler chickens.

\section{Livability (\%)}

In this present study, percentage of livability was insignificant among the dietary treatments suggesting that, CM did not cause any fatal effect to boiler chicken (Akintala et al., 2002), and can be used safely in broiler diets instead of using cereal grains (i.e maize and wheat).

\section{Meat yield characteristics}

The meat yield characteristics of broiler chickens regardless of dietary treatments were preserved the similar characteristics and insignificant in terms of statistical analysis, suggesting that dietary supplementation of $\mathrm{CM}$ and feeding time did not affect notably on the meat yield characteristics and different organs of broiler chickens (Awojobi and Adekunmi, 2002).

\section{Conclusion}

It would appear from the performance of the broiler chickens that cassava meal could be used to replace corn in broiler diets at levels up to 300 $\mathrm{g}$ cassava per $\mathrm{kg}$ diet. This view is supported by the fact that dried cassava root meal had no adverse effect on growth responses in terms of live weight and FCR, livability, and meat yield characteristics. However, although the feed intake of broilers fed on cassava treated diets was a little bit higher than the non-cassava or control diet in this study, but it would no longer affect the profitability of rearing broiler chickens, because the price of cassava is about half than that of the corn/maize. From the results of this experiment, it can be assumed that, the maximum level of cassava meal of the type used in the experiment, which could be included in broiler diets is about $30 \%$.

\section{References}

Akintala, E.O., Aderibigbe, A.O. and Matanmi, O. 2002. Evaluation of the nutritive value of cassava tuber meal as replacement for maize in the starter diets for broiler chicken. Cali, Colombia: CIPAV Foundation. 14: 1-6.

Awojobi, H.A. and Adekunmi, A. A. 2002. Performance of broilers fed graded levels of cassava tuber meal. New Delhi, India: Indian Council of Agricultural Research. 72: 1169-1172.

Bhatnagar, R., Kataria, M. and Verna, S.V.S. 1996. Effect of dietary Leucaena root meal on the performance and egg characteristics in white leghorn hens. Indian J. Animal Sci. 66 (12): 1291-1294.

Garcia, M. and Dale, N. 1999. Cassava root meal for poultry. Appl. Poultry Sci. 8: 132-137.

Hahn, S.K. 1989. An overview of African traditional cassava processing and utilization. Outlook on Agric. 18: 110-118.

Hossain, M.D., Bulbul, S.M. and Howlider, M.A.R. 1989. The composition of some unconventional feeds. Poultry Adviser. 22: 37- 40 .

Hughes, R.J . and Choct, M. 1999. Chemical and physical characteristics of grains related to variability in energy and amino acid availability in poultry. Australian J. Agril. Res. 50: 689-701. 
Mahmoudnia, N., Boldaji, F., Dastar, B. and Zereharan, S. 2011. Nutritional evaluation of poultry by-product meal in broiler chickens. Animal Biol. \& Animal Husbandry Int. J. Bioflux Soc. 3 (1) : 55-64.

Maust, L.E., Pond, W. G. and Choun, M. L. 2000. Energy value of cassava maize based diet with and without supplemental zinc for growing poultry. J . Animal Sci. 35: 935-957.

McNab, J . 1999. Advance in poultry nutrition in the world. Proceedings of the seminar and international poultry show, WPSA, Bnagladesh Branch. p. 52.

Minitab. 2000. Minitab Statistical Software User's Guide 2: Data Analysis and Quality Tools. Minitab Inc., State College, PA 16801-3008, USA.

Mroso, P.V. 2003. Cassava: An emerging food product, the consequence of its popularity. http:/ / www.suite1101.com/ article.Cfm/ 167 38/999964.

NRC. 1994. Nutrient Requirements of Poultry, 9th edn., National Research Council, National Academic Press, Washington, DC.

Oke, O.L. 1978. Problems in the use of cassava as animal feed. Feed Sci. Tech. 3 (4): 345-380.

Okezie, B.O. and Kosikowski, F.V. and Markakis, P. 1982. Cassava as food. Critical Rev. Food Sci. \& Nutri. 17 (3): 59-275.

Onjoro, P.A., Bhattacharjee, M. and Ottaro, J.M. 2001. Bioconversion of cassava tuber by fermentation into broiler feed of enriched nutritional quality. Trivandrum, India: Indian Society for Root Crops, Central Tuber Crops Research Institute. 24: 105110.

Onyimoyi, A.E. and Ugwu, S.O.C. 2007. Bioeconomic indices of broiler chicks fed varying ratios of cassava peel/ bovine blood. Int. J . Poultry Sci. 6 (5): 318-321.

Padmaja, G. 1995. Cyanide detoxification in cassava for food and feed uses. Critical Rev. Food Sci. \& Nutri. 35 (4): 299-339.

PAN. 1995. Annual Reports. Poultry Association of Nigeria. Lagos. Nigeria. 33: 34-37.
Phillips, T.P.,Taylor, D.S., Sanni, L. and Akoroda, M.O. 2004. A cassava industrial revolution in Nigeria: The potential for a new industrial crop. International Institute of Tropical Agriculture, Ibadan, Nigeria, International Fund for Agricultural Development, Food and Agriculture Organization of the United Nations, Rome, Italy. 43 p.

Piva, G. 1987. An evaluation of feeding stuffs: Alternatives for poultry diets. Feed International. J uly, 1987. pp. 26-30.

Raihan, S., Mahmud, N.T. and Linkages, P.A. 2008. Case study of the poultry industry in Bangladesh. Cuts International. pp. 1-15.

Ravindran, V. and Blair, R. 1991. Feed resources for poultry production for Asia and the Pacific regions. I Energy sources. World's Poultry Sci. J . 47: 213-231.

Ravindran, V., Kornegay, E.T. and Rajaguru, A.S. B. 1987. Influence of processing methods and storage time on the cyanide potential of cassava leaf meal. Animal Feed Sci. \& Tech. 17: 227-234.

Reed, J. D., McDowell, R. E., Van Soest, P. J . and Horvath, P. J. 1982.Condensed tannins: a factor limiting the use of cassava foliage. $\mathrm{J}$. Sci. Food \& Agric. 41: 45-53.

Singh, K. S. and Panda, B. 1992. Poultry Nutrition. Kalyani Publisher, New Delhi, India. p. 61.

Stevenson, M.H. and Jackson, N. 1983. The nutritional value of dried cassava root meal in broiler diets. J. Sci. Food \& Agric. 34: 1361-1367.

Tewe, O. 1993. Thyroid cassava toxicity in animals. pp. 114-118. In: Cassava toxicity end thyroid: research and public health issues, Proceedings, International Workshop on Cassava Toxicity, edited by F. Delange and R. Ahluwalia, 31 May-2 June 1993, Ottawa, Canada. IDRC-207e : Ottawa.

Van der Klis, J.D., Kwakernaak, C., Jansman, A. and Blok, M. 2010. Energy in poultry diets: Adjusted AME or Net Energy. Proceedings of Australian Poultry Science Symposium. 21: 44-49.

Vogt, H. 1966. The use of tapioca meal in poultry rations. World's Poultry Sci. J . 22: 113-125. 